\title{
WYBRANE MOŻLIWOŚCI ZASTOSOWANIA NANOSTRUKTUR W INŻYNIERII ŚRODOWISKA
}

\begin{abstract}
Obecnie ludzkość stoi przed wyzwaniami, jakie stanowią: remediacja środowiska, monitorowanie zanieczyszczeń oraz poszukiwanie czystych źródeł energii. W pracy prezentowane są perspektywy efektywnego zastosowania nanostruktur w katalitycznym i fotokatalitycznym rozkładzie zanieczyszczeń, w czujnikach toksycznych materiałów i w przyjaznych dla środowiska metodach wytwarzania energii z odnawialnych źródeł. Badania w dziedzinie nanotechnologii skupiają się na nanostrukturach, których wyjątkowe własności zależne od ich kształtów i rozmiarów pozwalają na szerokie potencjalne zastosowania. Wykorzystywanie nanostruktur umożliwia miniaturyzację urządzeń pracujących w różnych środowiskach np. w wodzie, powietrzu glebie, na wysypiskach śmieci i w innych zanieczyszczonych miejscach lub obiektach. Perspektywy zastosowań nanostruktur w inżynierii środowiska są interesujące dzięki ich szczególnym własnościom termicznym, mechanicznym, chemicznym, magnetycznym i optycznym. W pracy prezentowane są różne sposoby wykorzystania nanotechnologii. Spośród wielu perspektywicznych zastosowań nanostruktur, najbardziej interesujące w kontekście ochrony środowiska są następujące możliwości: katalityczny i fotokatalityczny rozkład toksycznych związków chemicznych, detekcja zanieczyszczeń, termoelektryczna konwersja energii oparta na zjawisku Seebecka i Peltiera jak również fotowoltaika. Użyteczne struktury, które mogą znaleźć zastosowania mają różnorodne formy. Mogą to być: nanocząstki $\mathrm{Fe}, \mathrm{TiO}_{2}, \mathrm{ZnO}$, nanokolumny $\mathrm{ZnO}$ pokryte radialnie przez kryształki $\mathrm{TiO}_{2}$ lub nanokolumny $\mathrm{ZnO} / \mathrm{V}_{2} \mathrm{O}_{5}$, jak również zbudowane z CdS/CdTe, InP, $\mathrm{Si}, \mathrm{InP} \mathrm{TiO}_{2} /$ metal szlachetny, nanorurki węglowe, nanodźwignie krzemowe, nanokompozyty typu half-Heuslers oraz $\mathrm{z}$ takich materiałów jak $\mathrm{PbTe}, \mathrm{CoSb}_{3}, \mathrm{BiTe}_{3}$.
\end{abstract}

Słowa kluczowe: kataliza, rozkład zanieczyszczeń, czujniki zanieczyszczeń, czysta energia

\section{Wstęp}

W związku ze wzrostem liczby ludności, rozwojem technologicznym i rosnącym zapotrzebowaniem na energię potrzebne są innowacyjne rozwiązania, które umożliwią zrównoważony rozwój. Obecnie duże zainteresowanie skupia

\footnotetext{
${ }^{1}$ Autor do korespondencji: Agata Zdyb, Wydział Inżynierii Środowiska, Politechnika Lubelska, ul. Nadbystrzycka 40B, 20-618 Lublin, tel./fax: (+081) 5381 997, tel: (+081) 5384747 , a.zdyb@pollub.pl
} 
rozwój nanotechnologii. Przedmiotem badań nanotechnologii są nanostruktury, które posiadają wyjątkowe, zależne od rozmiaru i kształtu własności, co umożliwia potencjalne zastosowania w wielu dziedzinach. Główną cechą nanostruktur różnych rodzajów, wykonanych z różnych materiałów jest duża wartość stosunku powierzchni do objętości dzięki czemu są one bardzo reaktywne, a ich własności mogą być dostosowywane do praktycznych celów. $\mathrm{Z}$ powodu bardzo małych rozmiarów nanostruktur ich własności są inne niż dla tych samych materiałów o dużej objętości. Zmieniona jest więc ich struktura, energia układu, jak również termiczne, mechaniczne, chemiczne, magnetyczne i optyczne własności. Nanostruktury mogą działać w skali nano, możliwa jest więc miniaturyzacja urządzeń, służących do oczyszczania powietrza, wody, gleby, a także na wysypiskach, terenach przemysłowych i w innych zanieczyszczonych miejscach. Ogólnie, perspektywy zastosowania nanocząstek w ochronie środowiska są bardzo obiecujące.

\section{Zastosowania nanostruktur}

Wyróżnić można wiele możliwości zastosowania nanostruktur w inżynierii środowiska. Jedną z nich jest katalityczny rozkład toksycznych związków chemicznych.

Efektywnym katalizatorem są nanocząstki żelaza, które zapewniają korzystne pod względem ekonomicznym możliwości rozkładu wielu rozpowszechnionych zanieczyszczeń. Struktury te są bardzo reaktywne w stosunku do zanieczyszczeń w glebie i wodzie [9]. Utrzymują własności katalityczne aż do 8 tygodni, a następnie rozpuszczają się w wodach gruntowych dając stężenia niższe niż naturalnie występujące żelazo. Nanocząstki Fe mogą być stosowane in situ ponieważ można je w prosty sposób wstrzykiwać do wód gruntowych ponad $20 \mathrm{~m}$ głęboko oraz ex situ w postaci warstwy osadzonej na aktywnym węglu lub krzemionce.

Katalityczne własności nanocząstek żelaza mogą być modyfikowane poprzez dodatek innych metali $(\mathrm{Pt}, \mathrm{Ag}, \mathrm{Ni}, \mathrm{Co}, \mathrm{Cu})$ i wówczas powstają struktury bimetaliczne. Są one bardziej reaktywne i stabilne, co zapewnia wzrost wydajności i szybkości reakcji. Nanostruktury oparte na żelazie mogą służyć w efektywnym rozkładzie wielu powszechnych zanieczyszczeń.

Inne zastosowanie nanostruktur $\mathrm{w}$ remediacji środowiska naturalnego to fotokataliza. W tym procesie półprzewodnikowe nanocząstki ditlenku tytanu zwykle stosowane są na dwa sposoby [3]. Pierwszy, w którym nanocząstki działają bezpośrednio absorbując promieniowanie UV i drugi, który związany jest $\mathrm{z}$ absorpcją światła widzialnego i udział nanocząstek jest pośredni. W pierwszym przypadku absorpcja fotonu powoduje wygenerowanie nośników ładunku elektrycznego, które następnie są rozseparowane i biorą udział w reakcjach redoks. W przypadku drugim na powierzchni $\mathrm{TiO}_{2}$ zaadsorbowana jest molekuła barwnika organicznego, który działa jak sensybilizator absorbujący światło 
widzialne. Wzbudzony elektron jest przekazywany ze stanu wzbudzonego barwnika do pasma przewodnictwa półprzewodnika, a sensybilizator regeneruje się lub ulega rozkładowi. W środowisku wodnym jako produkt reakcji powstaje aktywny tlen i rodniki $\mathrm{OH}^{*}$, które są silnymi utleniaczami i przekształcają cząsteczki zanieczyszczeń. W takich układach zarówno reakcje utleniania jak i redukcji biorą udział w mineralizacji toksycznych związków chemicznych.

Obiecującym materiałem do procesów fotokatalizy jest warstwa osadzonych nanocząstek $\mathrm{ZnO}$. Charakterystyczną cechą tego typu nanostruktury jest zdolność fluorescencji, w związku z tym pod wpływem promieniowania UV emitowane jest światło widzialne. Gdy na powierzchni $\mathrm{ZnO}$ znajdą się molekuły zanieczyszczeń ulegną one rozkładowi. Jednocześnie obserwowane jest wygaszenie fluorescencji, które stanowi informację o obecności innych cząsteczek na powierzchni $\mathrm{ZnO}$. W tym zastosowaniu warstwa półprzewodnikowych nanostruktur służy jednocześnie $\mathrm{w}$ detekcji i fotokatalitycznym rozkładzie zanieczyszczeń (Rys. 1). Opisany układ ma czułość $\sim 1$ ppm, może więc być wykorzystywany do badania jakości wody pitnej i wód podziemnych.

zanieczyszczenia
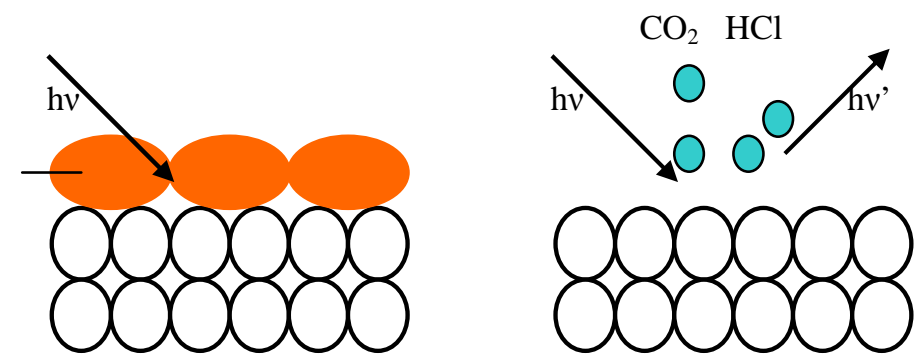

Rys. 1. Schemat wykrywania i rozkładu zanieczyszczeń organicznych

Fig. 1. The scheme of detection and decomposition of organic contaminations

W fotokatalitycznym rozkładzie zanieczyszczeń mogą brać udział nie tylko nanocząstki ale też nanostruktury innych kształtów. Interesującym przykładem są nanokolumny $\mathrm{ZnO}$ pokryte radialnie nanokryształkami $\mathrm{TiO}_{2}$.

Ten rodzaj struktury można otrzymać w kilku stosunkowo tanich i prostych etapach. Kolumny $\mathrm{ZnO}$ mogą być przygotowane poprzez syntezę z pary, mataloorganiczne chemiczne naparowanie (MOCVD) lub hydrotermalny wzrost z użyciem maski [10], który jest metodą nieszkodliwą dla środowiska. Otrzymane na szklanym podłożu nanostruktury $\mathrm{ZnO}$ pokrywane są przez warstwy $\mathrm{TiO}_{2}$ przy zastosowaniu rozpylania magnetronowego. Metoda ta jest bardzo czuła na wartość parametrów takich jak temperatura, tempo i czas osadzania.

W celu poprawienia wydajności katalizatora poprzez zwiększenie absorpcji światła w szerokim zakresie widma widzialnego mogą być stosowane również inne układy nanostruktur: $\mathrm{ZnO} / \mathrm{V}_{2} \mathrm{O}_{5}, \mathrm{TiO}_{2} /$ metal szlachetny. Badania nad fotokatalitycznym rozkładem zanieczyszczeń wykazują, że stosowanie nanokolumn jest korzystne. Porównanie tempa fotodegradacji przy użyciu różnych materia- 
łów np.: warstwy $\mathrm{TiO}_{2}$, podwójnej warstwy $\mathrm{ZnO} / \mathrm{TiO}_{2}$ i nanokolumn $\mathrm{ZnO} / \mathrm{TiO}_{2}$ wykazuje najlepszą wydajność dla tej ostatniej wymienionej struktury (Tabela 1). Prawdopodobnie główną przyczyną tego typu obserwacji jest bardzo duża wartość powierzchni właściwej nanokolumn $\mathrm{ZnO} / \mathrm{TiO}_{2}$.

Tabela 1. Porównanie tempa degradacji w przypadku zastosowania warstw $\mathrm{TiO}_{2}, \mathrm{TiO}_{2} / \mathrm{ZnO}$ i nanokolumn, dane na podstawie [10]

Table 1. Comparison of the degradation rate in case of using $\mathrm{TiO}_{2}, \mathrm{TiO}_{2} / \mathrm{ZnO}$ films and composite nanocolumn, data from [10]

\begin{tabular}{|l|c|c|}
\hline \multicolumn{1}{|c|}{ Próbka } & $\begin{array}{c}\text { Stężenie zanieczyszczeń } \\
\text { po 100 min. }\end{array}$ & $\begin{array}{c}\text { Stężenie zanieczyszczeń } \\
\text { po 200 min. }\end{array}$ \\
\hline Bez katalizatora & $100 \%$ & $100 \%$ \\
\hline WarstwaTiO & & $68 \%$ \\
\hline Warstwa $\mathrm{TiO}_{2} / \mathrm{ZnO}$ & $77 \%$ & $70 \%$ \\
\hline Nanokolumny $\mathrm{TiO}_{2} / \mathrm{ZnO}$ & $75 \%$ & $20 \%$ \\
\hline
\end{tabular}

Nanotechnologia dostarcza materiałów, które mogą być wykorzystywane także w innych zastosowaniach. Ochrona środowiska wymaga precyzyjnej detekcji zanieczyszczeń, w związku z tym obecnie rozwijane są nanostruktury do zastosowań w technologii czujników. Obiecującymi kandydatami do roli nanosensorów są nanorurki węglowe, które stanowią jedną z alotropowych odmian węgla. Mają one wyjątkowe własności takie jak duża powierzchnia właściwa, wysoka reaktywność i czułość, dobre przewodnictwo, silna zdolność adsorpcji molekuł, które dają możliwość miniaturyzacji czujników [7]. Schematycznie czujnik wykorzystujący nanorurki węglowe przedstawiony jest na Rys. 2 . W urządzeniu tego typu każda nanorurka generuje wokół niejednorodne pole elektryczne, co powoduje jonizację gazu. Przy danych wartościach przyłożonego napięcia pojawiają się impulsy prądu, a interpretacja otrzymanej charakterystyki I-V pozwala na identyfikację zanieczyszczeń.

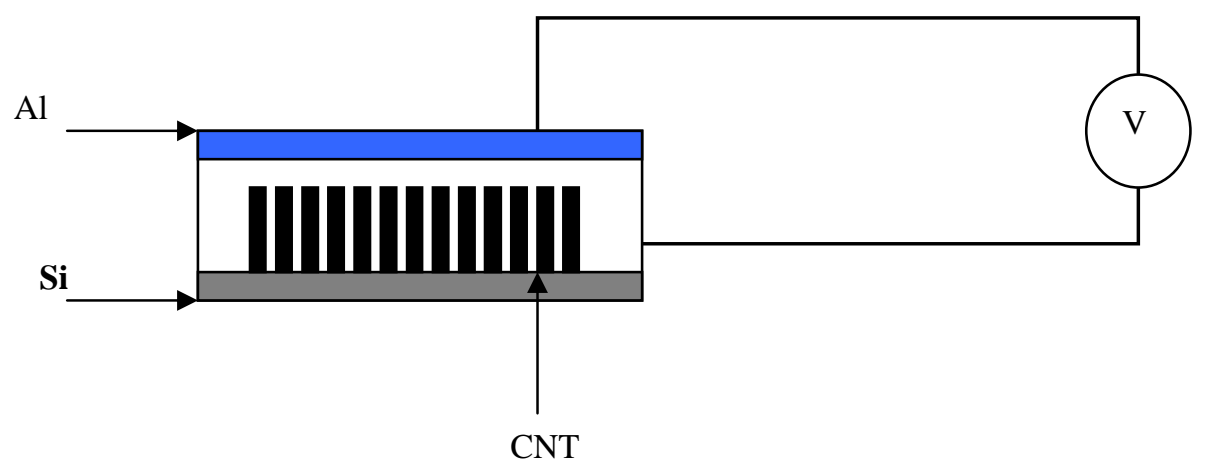

Rys. 2. Schemat sensora wykorzystującego nanorurki węglowe

Fig. 2. Scheme of sensor using carbon nanotubes 
Innym rodzajem czujnika jest urządzenie wykorzystujące układ dźwigni o grubości poniżej kilku mikrometrów [2]. Powierzchnia dźwigni jest pokryta przez materiał czuły na zanieczyszczenia. Osiadanie toksycznych molekuł powoduje ugięcie dźwigni, które jest rejestrowane jako odchylenie promienia laserowego odbitego od powierzchni dźwigni. Stopień ugięcia pozwala na oszacowanie masy zanieczyszczeń. Perspektywiczne zastosowania omówionych nanostruktur zestawione są w Tabeli 2.

Tabela 2. Zastosowania nanostruktur, dane na podstawie $[4,9$,10]

Table 2. Applications of different nanostructures, data from $[4,9,10]$

\begin{tabular}{|l|l|l|}
\hline \multicolumn{1}{|c|}{ Zastosowanie } & \multicolumn{1}{|c|}{ Materiały } & \multicolumn{1}{c|}{ Zanieczyszczenie } \\
\hline Kataliza & $\begin{array}{l}\text { nanostruktury } \mathrm{Fe}, \mathrm{Fe} / \mathrm{Pt}, \mathrm{Fe} / \mathrm{Ag}, \\
\mathrm{Fe} / \mathrm{Ni}, \mathrm{Fe} / \mathrm{Co}, \mathrm{Fe} / \mathrm{Cu}\end{array}$ & $\begin{array}{l}\text { pochodne metanu, benzenu, } \\
\text { etanu, pestycydy, barwniki } \\
\text { organiczne, metale ciężkie }\end{array}$ \\
\hline Fotokataliza & $\begin{array}{l}\text { nanostruktury } \mathrm{TiO}_{2}, \mathrm{ZnO} ; \\
\mathrm{ZnO}_{\mathrm{TiO}}, \mathrm{ZnO}_{2} \mathrm{O}_{5}, \\
\mathrm{TiO}_{2} / \mathrm{metal} \mathrm{szlachetny}\end{array}$ & $\begin{array}{l}\text { alkany, alkeny i ich pochodne } \\
\text { pestycydy, barwniki organiczne }\end{array}$ \\
\hline $\begin{array}{l}\text { Czujniki zanie- } \\
\text { czyszczeń }\end{array}$ & $\begin{array}{l}\text { nanorurki węglowe, nanodźwi- } \\
\text { gnie krzemowe }\end{array}$ & $\begin{array}{l}\mathrm{NO}_{2}, \mathrm{CO}, \mathrm{NH}_{3}, \text { toluen, heksan, } \\
\text { aceton, acetonitryl, metanol; } \\
\text { metale ciężkie, pestycydy, bak- } \\
\text { terie }\end{array}$ \\
\hline
\end{tabular}

Nanostruktury w formie nanokompozytu mogą być zastosowane w termoelektrycznej konwersji energii opartej na zjawiskach Seebecka i Peltiera. Źródłem energii do wytwarzania ciepła, chłodu i energii elektrycznej w przemianach termoelektrycznych może być energia promieniowania słonecznego lub ciepło odpadowe. Główną zaletę zastosowania nanokompozytów stanowią kanały do łatwego transportu elektronów i blokady drgań cieplnych [5]. Zastosowanie nanokompozytów: half-Heusler, $\mathrm{PbTe}, \mathrm{CoSb}_{3}, \mathrm{BiTe}_{3}$ pozwala osiągnąć lepsze wartości parametrów termoelektrycznych takich jak współczynnik termoelektryczny, współczynnik Seebecka, przewodnictwo elektryczne, współczynnik przewodnictwa cieplnego.

Inne podejście w poszukiwaniu czystej i taniej energii stanowi fotowoltaika wykorzystująca nanokolumny. W technice tej układy nanokolumn CdS/CdTe, InP, Si używane są w ogniwach słonecznych, co zapewnia zwiększenie wydajności absorpcji światła jak również ułatwienie transportu nośników ładunku [4]. Nanokolumny CdS można otrzymywać na kilka sposobów. Jednym $\mathrm{z}$ nich jest proces, $\mathrm{w}$ którym nanokolumny rosną na podłożu z porowatego tlenku glinu z Au naniesionym na dnie każdego z porów. Następnie podłoże jest trawione i nanokolumny są pokrywane warstwą CdTe oraz warstwą metalicznego kontaktu. Sposób ten stanowi tanią metodę, która umożliwia seryjną produkcję struktury fotowoltaicznej. Tabela 3 przedstawia para- 
metry charakteryzujące nanokolumnowe ogniwa słoneczne. Najlepsza wydajność została osiągnięta przy zastosowaniu nanokolumn InP, jednakże wszystkie zaprezentowane wartości wymagają dalszej poprawy.

Ogólnie, głównym wyzwaniem w rozwoju fotowoltaiki jest poprawa wydajności i obniżenie kosztów. Zalety zastosowania nanokolumn takie jak: maksymalizacja absorpcji światła, redukcja strat przy odbiciu i używanie tanich podłoży umożliwiają osiągnięcie wyznaczonego celu.

Tabela 3. Parametry pracy ogniw słonecznych, na podstawie $[4,1]$

Table 3. Parameters of nanopillar solar cells, data from $[4,1]$

\begin{tabular}{|l|c|c|c|}
\hline \multicolumn{1}{|c|}{ Material } & $\begin{array}{c}\text { Gęstość prądu } \\
\text { zwarcia [mA/cm }{ }^{2} \text { ] }\end{array}$ & $\begin{array}{c}\text { Napięcie obwodu } \\
\text { otwartego [V] }\end{array}$ & Sprawność [\%] \\
\hline $\begin{array}{l}\text { Nanokolumny } \\
\text { InP }\end{array}$ & 25 & 0,54 & 8,1 \\
\hline $\begin{array}{l}\text { Nanokolumny } \\
\text { CdS/CdTe }\end{array}$ & 21 & 0,6 & 6 \\
\hline $\begin{array}{l}\text { Nanokolumny } \\
\mathrm{Si}\end{array}$ & 16,45 & 0,525 & 4,83 \\
\hline
\end{tabular}

\section{Wnioski}

W pracy zaprezentowane zostały różne podejścia do zastosowania nanotechnologii w remediacji środowiska naturalnego. Aktualny poziom rozwoju nanotechnologii pozwala projektować i wytwarzać nanostruktury o różnych formach np. nanocząstki, nanorurki, nanodźwignie i nanokolumny. Wszystkie z nich mają szczególne własności, które perspektywicznie pozwalają na zastosowanie ich w katalizie, fotokatalizie, czujnikach zanieczyszczeń oraz czystych metodach konwersji energii słonecznej.

\section{Literatura}

[1] Cho K., Ruebusch D.J., Lee M.H., Moon J.H., Ford A.C., Kapadia R., Takei K., Ergen O., Javey A.: Molecular Monolayers for Conformal, Nanoscale Doping of InP Nanopillar Photovoltaics, Applied Physics Letters, vol. 98, no. 20, 2011, pp. 203101-1 - 203101-3.

[2] Filipponi L., Sutherland D.: Nanoyou Teachers Training Kit in Nanotechnologies, European Commision Document, Denmark, 2010.

[3] Kamat P.V., Meisel D.: Nanoscience opportunities in environmental remediation. C.R. Chimie, vol. 6, no. 8, 2003, pp. 999-1007.

[4] Kapadia R., Fan Z., Takei K., Javey A.: Nanopillar photovoltaics: Materials, processes, and devices. Nano Energy, vol. 1, no. 1, 2012, pp. 132-144. 
[5] Liu W., Yan X., Chen G., Ren Z.: Recent advances in thermoelectric nanocomposites, Nano Energy, vol. 1, no. 1, 2012, pp. 42-56.

[6] Modi A., Koratkar N., Lass E., Wei B., Ajayan P.M.: Miniaturized Gas Ionization Sensors Using Carbon Nanotubes, Nature, vol. 424, no. 6945, 2003, pp. 171-174.

[7] Pan B., Xing B.: Adsorption Mechanisms of Organic Chemicals on Carbon Nanotubes. Environmental Science \& Technology, vol. 42, no. 24, 2008, pp. 9005-9013.

[8] Shanov V., Yun Y.-H., Schulz M.J.: Synthesis and Characterization of Carbon Nanotube Materials. Journal of the University of Chemical Technology and Metallurgy, vol. 41, no.4, 2006 pp. 377-390.

[9] Zhang W.-x.: Nanoscale iron particles for environmental remediation: An overview. Journal of Nanoparticle Research, vol. 5, 2003, pp. 323-332.

[10] Zou C.W., Gao W.: Fabrication, Optoelectronic and Photocatalytic Properties of Some Composite Oxide Nanostructures. Transaction on Electrical and Electronic Materials, vol. 11, no. 1, 2010, pp. 1-10.

\title{
PROSPECTIVE APPLICATIONS OF NANOSTRUCTURES IN ENVI- RONMENTAL ENGINEERING
}

\begin{abstract}
S u m m a r y
Nowadays humanity faces with the challenge of environmental remediation, pollution monitoring and searching for clean energy sources. This paper presents the prospects for successful utilizing of nanostructures in environmental applications including catalytic and photocatalytic decomposition of contaminations, pollution sensing and production of clean energy. Nanotechnology researches focus on nanostructures which exceptional size and shape dependent properties allow for potential applications in many fields. Application of nanostructures provides possibility to miniaturise devices working in different environments like water, air, soil, landfills and other contaminated sites. There are interesting prospects for successful usage of nanoparticles in environmental engineering because of their specific thermal, mechanic, chemical, magnetic and optical properties. In this paper, different approaches of nanotechnology applications were presented Among many possible applications of nanostructures in the context of environmental protection, especially interesting are: catalytic decomposition of toxic chemicals, photocatalysis, accurate detection of contaminations, thermoelectric energy conversion based on Seebeck and Peltier effect, photovoltaics. The useful structures that can find applications have different forms like nanoscale iron particles, titanium dioxide semiconductor particles, $\mathrm{ZnO}$ nanoparticles, composites of nanostructures like $\mathrm{ZnO}$ nanocolumns covered radially by $\mathrm{TiO}_{2}$ nanocrystals and $\mathrm{ZnO} / \mathrm{V}_{2} \mathrm{O}_{5}$, $\mathrm{TiO}_{2}$ /nobel metal, carbon nanotubes, silicon nanocantilevers, nanocomposite materials including half-Heuslers, $\mathrm{PbTe}, \mathrm{CoSb}_{3}, \mathrm{BiTe}_{3}$, nanopillars made of CdS/CdTe, InP, Si, InP nanocolumns.
\end{abstract}

Keywords: catalysis, decomposition of contaminations, pollution sensing, clean energy

Przestano do redakcji: 22.11.2014 r.

Przyjęto do druku: 22.06.2015 r.

DOI:10.7862/rb.2015.90 